\title{
Impact of Training Programme and Establishment of Entrepreneurial Activities on Nutrition Knowledge, Awareness and Empowerment of Rural Women
}

\author{
A.M. Maruthesha*, B. Manjunath and G.B. Jagadeesh \\ Agricultural and Horticultural Research Station, Kathalagere - 577219 (Karnataka), India \\ *Corresponding author
}

\section{A B S T R A C T}

Keywords

Impact,

Entrepreneurship

development,

Training, and Value addition

Article Info

Accepted:

22 May 2018

Available Online:

10 June 2018

The present study on entrepreneurship development among rural women was conducted in selected villages of Bangalore rural district in Karnataka state. The selected villages were Heggadehalli of Doddballapur taluk and Venkatahalli of Devanahalli taluk during the year 2013-14. The data was collected from the 200 rural women using semi structured interview schedule. The collected data was analysed using appropriate statistical tools. The results of the study revealed that, the consumption of cereals met highest (96\%) adequacy followed by green leafy vegetables $(81 \%)$ sugar and jaggery $(80 \%)$ and least adequacy was observed in case of fruits $(50.00 \%)$ before the intervention. But after the intervention, the adequacy of all the foods increased and it was 77 per cent in case of fruits. With respect to nutrient intake similar trend was observed for protein, energy, fat as well as iron, however 118 per cent adequacy was achieved for calcium after intervention. The impact of training programme organized revealed that, the SHG women strongly agreed that entrepreneurial activities helped to improve their knowledge after the training programme like general nutrition $(84 \%)$, health and hygiene $(78 \%)$, nutritional deficiency diseases $(68 \%)$, benefits of anganawadi and mid day meals (58\%).

\section{Introduction}

Empowering rural women needs a holistic approach to participate in decision making in the household, community and local domestic sector and prepare women to take up leadership position in agricultural activities. SHGs in rural India are causing a silent revolution not only in terms of providing access to micro credit to communities but also in contributing towards a greater sustainability in agriculture in various ways, including through a better use of marginalized local agro biodiversity.

Life style changes in society, new advances in food technology and packaging, increased interest in healthy eating of more nutritious foods. Change in meal pattern, existing food habits and increased demand for home entertainment (radio and television) have increased the demand for creation of new market for value added processed food products. Apart from value addition by 
processing to traditional products like cereals, millets and pulses development of newer products offers variety, convenience, quality, cost efficiency and scope for increasing the nutritional value.

Further, finger millet contains more calcium than other cereals, it is also rich in iron, vitamins, minerals and amino acids. Finger millet foods contain most desirable characteristics of healthy foods, therefore it is unique consummate functional food. Considering the above it is important to harness nutritional and health promoting components to meet the desire need of population through fortification and value addition, at the same time there is opportunity to empower the rural SHG women groups in developing these finger millet value added products as a cottage industry. Hence, the research study was carried out on empowerment of rural women towards food security through agro-processing activities.

\section{Materials and Methods}

The present study on socio-economic characteristics, food habits and dietary intake of rural women was conducted in selected villages of Bangalore rural district in Karnataka state. The selected villages were Heggadehalli of Doddballapur taluk and Venkatahalli of Devanahalli taluk during the year 2013-14. The villages selected come in the frame work of the project on "Partnering with higher education in India for improving nutritional quality of food by biotechnology approaches" funded by USAID. Ninety rural women from Heggadehalli village and 110 rural women from Venkatahalli village were selected randomly for the study, thus making a total sample of 200 respondents.

A pilot study was conducted to determine the feasibility of the study and validity of the questionnaire. The pilot study was conducted on 10 per cent of the sample Size. The study used both qualitative and quantitative assessment measures. The data was collected from the respondent rural women using semi structured interview schedule developed for the study. The collected data was tabulated and analysed using appropriate statistical tools like frequency, parentage, mean, standard deviation, correlation etc., to draw valid conclusions.

\section{Results and Discussion}

\section{Socio-economic characteristics of rural women}

Socio-economic characteristics of rural women were depicted in Table 1. It was observed that majority of rural women were found to be in the age group of 21- 25 years, followed by 26- 35 years. Middle aged women are generally enthusiastic and innovative nature. The young women will be having the indication to take risks and need for achievement in general. The findings are in conformity with those findings of Ganeshamurthy et al., (2004) and Tara and Negi (2012) who have revealed that majority of the rural women belonged to middle age group.

Most of the rural women (33\%) were literates i.e., 34 per cent of them had primary school followed by 12 per cent secondary school, 14 per cent had high school level of education, and remaining 7 per cent of the rural women were graduates. These findings are in line with the findings of Mamatha and Chaya (2012) who observed that majority of rural women studied upto primary school level.

Occupation of the rural women, that is 26 per cent of them were housewives, 40 per cent of them labourers, 24 per cent of them were involved in dairy, 6 per cent in sericulture and 4 per cent in other activities. These findings are in line with George et al., (2009) and Gurumeet and Gurudarshan (2011). 
It was observed that majority of the rural families $(63 \%)$ were marginal farmers, 16 per cent of them were small farmers, 11 per cent of them were medium farmers and only 10 per cent were large farmers.

Land holding of the subjects indicated that majority of them belonged to the marginal land holding category (63\%) followed by small farmer category $(16 \%)$. It clearly indicates that the low economic status particularly rural women have low earning power and also may be because of the fragmentation and subdivision of agricultural lands by the members of the family. The findings of the present study agree with the findings of Revanna (2006) and Raksha et al., (2012).

From the same table it is clear that 16 per cent of the rural families' income ranged between Rs. 2,000-3,000, followed by 56 per cent with the income of Rs. 3,000 per month. And only 28 per cent of the families are in the range of Rs.4,000- Rs.5,000. These findings have also been observed by Chethana (2005) and Mamatha and Chaya (2012) who reported that a majority of the landless (84\%) and marginal (72\%) households had income in the range of Rs. 685 to Rs. 3,585 per month.

The total income of the rural women comes from various sources namely land, livestock, labour wages, sericulture, petty business and small-scale entrepreneurship for the annual income of Rs.38,260.00 per annum (Table 2). This might be because of multiple source of income among the rural families. Their findings are on par with values reported by Das and Mishra (2012). Hence, there is an urgent need to educate the women about their strength, skill training particularly to motivate them, sufficient loans should be provided to them and also marketing is required to sustain their interest. Along with this the family member awareness should be improved about the importance of the economic support by the women in the family. The result has been in line with the study conducted by Mamatha and Chaya (2012) who pointed that monthly workshops should emphasis more and more on skill teaching and field visits besides being a forum for exchange of technical information.

\section{Impact of intervention on consumption of foods by rural women in comparison with RDA}

Table 3 reveals the impact of intervention on consumption of foods by rural SHG women in comparison with RDA. Among the different food groups cereals consumption met (96\%) adequacy followed by green leafy vegetables $(81 \%)$ sugar and jaggery $(80 \%)$ and least percentage of adequacy was met for fruits $(50 \%)$. After intervention of nutrition education there was a significant change in the consumption of different food groups. Cereals (98\%), other vegetables (90\%), sugar and jaggery $(86 \%)$, green leafy vegetables $(84 \%)$, pulses $(82 \%)$ and fruits consumption increased to 77 per cent adequacy. However none of the food groups met $100 \%$ adequacy. Deshpande et al.(2003) in their study reported that cereals, pulses, milk and milk products and fruits showed deficits of intake among rural women labourers from Tamilnadu. Similar observations were reported on agricultural women labourers by Radhai (2000). The reasons for enhancement in food intake adequacy after training programme and entrepreneurial activity was due to increase in income and level of education. Suman and Geetha (2003) assessed the adequacy of food intake by farm women, even in this study diets of women was inadequate in quantity and poor in quality. Cereals/ millets consumed proportionately more than pulses indicating the serious imbalance of cereals and pulses ratio. Among rural women, low intake of fat could be attributed to the lower income where there is tendency to consume lower amounts of fats and oils. 
Table.1 Socio-economic characteristics of rural women

\begin{tabular}{|c|c|c|c|}
\hline \multirow{2}{*}{$\begin{array}{l}\text { SI. } \\
\text { No. }\end{array}$} & \multirow[t]{2}{*}{ Variables } & \multicolumn{2}{|c|}{ Respondents $(\mathrm{n}=\mathbf{2 0 0})$} \\
\hline & & No. & Per cent \\
\hline \multirow[t]{4}{*}{1.} & \multicolumn{3}{|l|}{ Age } \\
\hline & $21-25$ years & 130 & 65.00 \\
\hline & $26-35$ years & 62 & 31.00 \\
\hline & $36-40$ years & 08 & 04.00 \\
\hline \multirow[t]{6}{*}{2.} & \multicolumn{3}{|l|}{ Education } \\
\hline & Illiterate & 66 & 33.00 \\
\hline & Middle school & 68 & 34.00 \\
\hline & High school & 24 & 12.00 \\
\hline & SSLC & 28 & 14.00 \\
\hline & Graduate & 14 & 07.00 \\
\hline \multirow[t]{3}{*}{3.} & \multicolumn{3}{|l|}{ Family type } \\
\hline & Joint & 54 & 27.00 \\
\hline & Nuclear & 146 & 73.00 \\
\hline \multirow[t]{4}{*}{4.} & \multicolumn{3}{|l|}{ Family size } \\
\hline & Small (upto 3 members) & 28 & 14.00 \\
\hline & Medium (4-6 members) & 166 & 83.00 \\
\hline & Large ( 7 and above) & 06 & 03.00 \\
\hline \multirow[t]{5}{*}{5.} & \multicolumn{3}{|l|}{ Land holding } \\
\hline & Marginal farmers (<2.5acres) & 126 & 63.00 \\
\hline & Small farmers (2.5-5.0 acres) & 32 & 16.00 \\
\hline & Medium farmers (> 5.0 acres) & 22 & 11.00 \\
\hline & Land less & 20 & 10.00 \\
\hline \multirow[t]{6}{*}{6.} & \multicolumn{3}{|l|}{ Occupation } \\
\hline & House wife & 52 & 26.00 \\
\hline & Labourer & 80 & 40.00 \\
\hline & Agriculture with Dairy & 48 & 24.00 \\
\hline & Sericulture & 12 & 6.00 \\
\hline & Other activities & 08 & 4.00 \\
\hline \multirow[t]{5}{*}{7.} & \multicolumn{3}{|l|}{ Family Income / month } \\
\hline & $<$ Rs. 2,000 & 32 & 16.00 \\
\hline & Rs. $2,000-3,000$ & 112 & 56.00 \\
\hline & $>$ Rs. 3,000 & 56 & 28.00 \\
\hline & Total & 200 & 100 \\
\hline
\end{tabular}


Table.3 Impact of intervention on consumption of foods by rural women in comparison with RDA

$$
(\mathbf{n}=\mathbf{5 0})
$$

\begin{tabular}{|c|c|c|c|c|c|c|c|c|}
\hline \multirow[t]{2}{*}{ Food group } & \multirow[t]{2}{*}{ RDA } & \multicolumn{2}{|c|}{ Before } & \multirow[t]{2}{*}{$\%$ adequacy } & \multicolumn{2}{|l|}{ After } & \multirow[t]{2}{*}{$\%$ adequacy } & \multirow[t]{2}{*}{ ' $t$ ' test } \\
\hline & & Mean & SD & & Mean & SD & & \\
\hline Cereals & 330 & 320 & 89.8 & 96 & 326 & 80.5 & 98 & $60.61 * *$ \\
\hline Pulses & 75 & 58 & 19.7 & 77 & 62 & 17.4 & 82 & $33.28 * *$ \\
\hline Green leafy vegetables & 100 & 81 & 16.4 & 81 & 84 & 12.9 & 84 & $28.28 * *$ \\
\hline Other vegetables & 200 & 150 & 54.6 & 75 & 181 & 46.2 & 90 & $47.14 * *$ \\
\hline Fruits & 100 & 50 & 18.6 & 50 & 77 & 34.1 & 77 & $30.30 * *$ \\
\hline Milk and milk products & 300 & 200 & 66 & 76 & 242 & 70.5 & 80 & $46.04 * *$ \\
\hline Fat and oil & 25 & 18 & 4.8 & 72 & 19 & 4.2 & 76 & $23.57 * *$ \\
\hline Sugar and jaggery & 30 & 24 & 8.9 & 80 & 26 & 8.1 & 86 & $70.71 * *$ \\
\hline
\end{tabular}

** Significant at $1 \%$ level

Table.4 Impact of intervention on mean nutrient intake of rural women comparison with RDA

\begin{tabular}{|l|}
\hline Nutrients \\
\hline Protein (gm) \\
\hline Fat (gm) \\
\hline Energy (k.cal) \\
\hline Calcium (mg) \\
\hline Iron (mg) \\
\hline
\end{tabular}

\begin{tabular}{|l|l|l|l|}
\hline RDA & \multicolumn{2}{|l|}{ Before } & $\%$ adequacy \\
\cline { 2 - 3 } & Mean & SD & \\
\hline 55 & 35.3 & 12.5 & 64 \\
\hline 25 & 16.3 & 7.9 & 65 \\
\hline 2230 & 1850 & 442.3 & 83 \\
\hline 600 & 695 & 117.6 & 115 \\
\hline 21 & 14 & 7.4 & 66 \\
\hline
\end{tabular}

\begin{tabular}{|l|}
\hline After \\
\hline Mean \\
\hline 41.0 \\
\hline 18.6 \\
\hline 2108 \\
\hline 712 \\
\hline 16.5 \\
\hline
\end{tabular}

\begin{tabular}{|l|l|}
\hline SD & \% adequacy \\
\hline 11.9 & 74.0 \\
\hline 8.4 & 74.5 \\
\hline 431.2 & 94.5 \\
\hline 112.8 & 118.0 \\
\hline 8.4 & 78.0 \\
\hline
\end{tabular}

\begin{tabular}{|l|l|}
\hline Paired & $6 t^{\prime}$ test \\
\hline $48.08 * *$ \\
\hline $23.23 * *$ \\
\hline $38.77 * *$ \\
\hline $28.62 * *$ \\
\hline $24.26 * *$ \\
\hline
\end{tabular}

** Significant at $1 \%$ level 
Table.2 Average annual income from different source of the rural families

\begin{tabular}{|l|}
\hline Source of income \\
\hline Agriculture \\
\hline Livestock \\
\hline Sericulture \\
\hline Labour wages \\
\hline Petty business and other sources \\
\hline Total \\
\hline
\end{tabular}

\begin{tabular}{|l|l|l|}
\hline No. @ & Income (Rs.) & SD \\
\hline 156 & 9,560 & $1,421.60$ \\
\hline 124 & 8,600 & 972.00 \\
\hline 15 & 7,600 & 638.20 \\
\hline 72 & 6,700 & $2,903.40$ \\
\hline 80 & 5,800 & $2,451.05$ \\
\hline & $\mathbf{3 8 , 2 6 0}$ & $\mathbf{8 , 3 8 6 . 2 5}$ \\
\hline
\end{tabular}

@ Multiple response

Table.5 Impact of training programme on nutrition knowledge, awareness and empowerment of rural women

\begin{tabular}{|c|c|c|c|c|c|}
\hline \multirow[t]{2}{*}{ Nutrition Knowledge } & \multicolumn{2}{|l|}{ Before } & \multicolumn{2}{|l|}{ After } & \multirow[t]{2}{*}{$\mathrm{X}^{2}$ test } \\
\hline & Number & $\begin{array}{l}\text { Per } \\
\text { cent }\end{array}$ & Number & $\begin{array}{l}\text { Per } \\
\text { cent }\end{array}$ & \\
\hline General nutrition & 11 & 22 & 42 & 84 & $211.51 * *$ \\
\hline Health and Hygiene & 12 & 24 & 39 & 78 & $171.91 * *$ \\
\hline Nutritional deficiency diseases & 6 & 12 & 34 & 68 & $171.07 * *$ \\
\hline $\begin{array}{l}\text { Anganawadi /mid day meal } \\
\text { benefits }\end{array}$ & 12 & 24 & 29 & 58 & $96.13 * *$ \\
\hline \multicolumn{5}{|c|}{ A wareness about finger millet products } & \\
\hline Processing & 20 & 40 & 44 & 88 & $208.70 * *$ \\
\hline Quality control practices & 16 & 16 & 38 & 76 & $215.77 * *$ \\
\hline $\begin{array}{l}\text { Packaging, branding and } \\
\text { labelling }\end{array}$ & 14 & 28 & 40 & 80 & $239.10 * *$ \\
\hline Marketing & 16 & 32 & 38 & 76 & $194.82 * *$ \\
\hline \multicolumn{6}{|l|}{ Empowerment } \\
\hline Labour employment & 27 & 54 & 46 & 92 & $76.29 * *$ \\
\hline Financial independence & 30 & 60 & 42 & 84 & $44.27 * *$ \\
\hline Improvement in self confidence & 21 & 42 & 46 & 92 & $75.68 * *$ \\
\hline $\begin{array}{l}\text { Realizing importance of } \\
\text { education }\end{array}$ & 24 & 48 & 40 & 80 & $61.45 * *$ \\
\hline Overall personality development & 16 & 32 & 42 & 84 & $120.55^{* *}$ \\
\hline
\end{tabular}

@ Multiple responses

** Significant at $1 \%$ levels

Impact of intervention on mean nutrient intake of rural women comparison with RDA

With respect to nutrient intake similar trend was observed for protein, energy, fat as well as iron, however 118 per cent adequacy was achieved for calcium after intervention (Table 4). The changes in the nutrient intake after training programme was due to enhanced nutrition knowledge, awareness about cooking methods and other activities. Similar observations were made by Dobhal and Raghuvanshi (2001) on urban and rural women of garwal region of Uttarakhand. Similar findings are in line with 
RBRC project (2010) report that, the general awareness of rural women with respect to nutrition, health and awareness on marketing was assessed before the training programme, majority of the women were not aware of the balanced diet and micronutrient deficiencies, however post education sessions showed increased percentage of knowledge (32-84\%) with an enhancement of awareness about general nutrition, health and hygiene and deficiency diseases (24.6-83\%). Hence, nutrition education to the rural women is important in the dissemination of knowledge and create awareness on food consumption and nutrient intake as well as food processing and value addition for income generation.

\section{Impact of training programme on nutrition knowledge, awareness and empowerment of rural women}

Impact of training programme of SHG rural women on nutrition knowledge and awareness and empowerment of women before and after the training programme is depicted in Table 5. The results revealed that the SHG women strongly agreed that entrepreneurial activities helped to improve their knowledge after the training programme like general nutrition $(84 \%)$, health and hygiene $(78 \%)$, nutritional deficiency diseases (68\%), benefits of anganawadi and mid day meals (58\%). With regard to awareness about finger millet products 88 per cent of SHG women expressed that packaging, branding and labelling are very important followed by processing (80\%), quality control practices like safety practices HACCP (76\%) and marketing (76\%). SHG women strongly opined that entrepreneurial activities helped them to improve their socioeconomic status in terms of labour employment (92\%), and financial independence (84\%). Hence, they also felt that there was an improvement in individual sphere through increasing their self confidence (92\%), realising importance of education $(80 \%)$ and development of overall personality (84\%). Further, the improvement of entrepreneurial activities on the status had relatively more pronounced in empowerment. So there was improvement in the quality of life in terms of increased family income, gaining self confidence, productive use of free time and also more recognition in the family.

Thus, the entrepreneurial activities contributed towards the reduction of poverty and unemployment of the rural SHG women. The findings of the study was supported by the results of other studies in sphere of socioeconomic situation of the SHG women and are in line with study conducted by Vijayalakshmi et al., (2007).It is clearly evident that the SHG women enhanced their skills and self confidence, leadership qualities and income by undertaking income generating activities.

\section{Summary and conclusions}

The results of the study revealed that, majority of the rural women were marginal farmers $(63 \%)$ and earn an average monthly income between Rs. 2,000-3,000 per month. The average annual income of the rural families was Rs. 38,260 from agriculture and allied activities. There was a considerable difference in monthly expenditure on food and non food items due to significant difference in economic status. Nutrient intake of rural women was compared with RDA. The intake of all nutrients viz. energy, protein, fat, iron, thiamine, riboflavin, niacin and $\beta$-carotene were low except for calcium. Therefore it is the need of the hour that, the extension agencies involved in ruaral development should concentrate more on rural women and organize extension programmes for the benefit of the rural women. The training interventions by the research played a strategic role by increasing self confidence of SHGs in undertaking small scale food processing of value added products of finger millet and capacity building of women

\section{References}

Chethana, M.P., 2005, Impact of shreeshakthi programme on farm women in Tumkur 
district. M.Sc. (Agri) thesis, UAS, Bangaluru.

Das, and Mishra, 2012, Effectiveness of training programme on mainstreaming gender and women empowerment. J.Extn.Edu.,24(4): 4907-4912.

Deshpande, S. S., Mishra, A., and Mishra, M., 2003, Nutritional profile of farm women of Madhya Pradesh and impact of nutrition education on the inclusion of soya bean products. The Ind. J. Nutr.Dietet.,40: 185-187.

Dobhal, N. and Raghuvanshi, R. S., 2011, Nutritikon and health status of urban and rural women of Garhwal Region. Ind. J. Nutri and Dietet., 48(9): 377389.

Ganeshamurthy, V.S., Radhakrishnan, M.K., Bhuvaneshwari, S. and Ganeshan, A., 2004, A study on thrift and credit utilization pattern of SHG, in Lakshmi villas bank, Suryampallam branch, Erod.Ind.J.Market., 34(1): 12-24.

George, P.R., Shibu, C.N. and Balakrishnan, P.P., 2009, Socio-economic profile of rural women and the role of animal husbandry intervention in suicide affected district of Kerala. J.Hu.Ecol., 27(1): 41-44.

Gurumeeth, S. and Gurudarshan, S., 2011, Socio-economic status of small and marginal farmers and without subsidiary occupation in central Punjab.Ind.J.Soci.Res., 52(2): 183-189.

Mamatha, D. and Chaya, B., 2012, Awareness and opinion of devadasis on selected income

generating
activities.Kar.J.Agrl.Sci., 25(1): 120123.

Radhai Sri, S., 2000, Nutritional profile of agricultural women labourers and impact of an iron rich food supplements on moderate anemic women. Ph.D. thesis (unpublished). Avinash Lingam Deemed University, Coimbatore, Tamil Nadu.

Raksha, Rita, G., and Lali, Y., 2012, Constraints faced by rural women in procurement and utilization of credit facilities in Hissar district.J. Rese ANGRAU., 4(4): 29-35.

RBRC, 2010, Project report submitted to DBT, New Delhi from UAS, Bangaluru. pp 56-64.

Revanna, M.L., 2006, Impact of WYTEP on empowerment and nutritional status of farm women: A study in MandyaDistrit. PhD Thesis, University of Agricultural sciences, Bangalore.

Suman, B. and Geetha, C., 2003, Dietary profile of women in a village of eastern Uttar Pradesh The Ind. J. Nutr. Diet., 40: 455-461.

Tara, N. and Negi, V., 2012, Rural women involvement in selected entrepreneurial activities. Adv. Res. J. Soc. Sci., 3(1): 63-67.

Vijayalakshmi, D., Roopa, V. T., and Chengappa, P.G., 2007, Empowerment of women members of self-help group through training and value addition. International seminar on challenges to sustainable agri food systems, Bengaluru, India, 73-82.

\section{How to cite this article:}

Maruthesha, A.M., B. Manjunath and Jagadeesh, G.B. 2018. Impact of Training Programme and Establishment of Entrepreneurial Activities on Nutrition Knowledge, Awareness and Empowerment of Rural Women. Int.J.Curr.Microbiol.App.Sci. 7(06): 3311-3318. doi: https://doi.org/10.20546/ijcmas.2018.706.388 